Polasik M., Piotrowski D., Payment innovations in Poland: a new approach of the banking sector to introducing payment solutions, „Ekonomia i Prawo. Economics and Law”, Polszakiewicz B., Boehlke J. (ed.), Vol. 15, No. 1/2016, pp. 103-131. DOI: http://dx.doi.org/10.12775/ EiP.2016.007.

\author{
Michat Polasik*, Dariusz PIOTROWSKI ${ }^{* *}$
}

\title{
PAYMENT INNOVATIONS IN POLAND: A NEW APPROACH OF THE BANKING SECTOR TO INTRODUCING PAYMENT SOLUTIONS ${ }^{\diamond}$
}

\begin{abstract}
One of the key challenges facing banks is the impact of disruptive new technologies on their retail payments business - the so-called "rise of the FinTech"

Yves Mersch, Member of the Executive Board of the ECB, European Financial Forum, Cumberland Lodge, 12 November 2015
\end{abstract}

\section{SUMMARY}

The aim of our work is to determine the involvement and plans of banks concerning the introduction of payment innovations in the Polish market. This empirical study was based on the results of two surveys. The first survey allowed us to obtain the official positions of 24 commercial banks. The second survey included the opinions of 70 experts, who were senior managers from banks and other payment mar-

"Michał Polasik, Nicolaus Copernicus University, Faculty of Economic Sciences and Management, Departament of Finance, ul. Gagarina 13A, 87-100 Toruń, Poland, phone: +48 5661146 34, e-mail: michal.polasik@umk.pl (corresponding author).

** Dariusz Piotrowski, Nicolaus Copernicus University, Faculty of Economic Sciences and Management, Departament of Finance, ul. Gagarina 13A, 87-100 Toruń, Poland, phone: +48 5661146 34, e-mail: darius@econ.umk.pl.

$\checkmark$ The article was funded by The Warsaw Institute of Banking and ALTERUM Grant No. WIB/2014/01. We would like to thank Anna Iwona Piotrowska and Natalia Kumkowska, who served as investigators. Moreover, we would like to thank Lech Kukliński, Ph.D. the director of ALTERUM and director Paweł Widawski Ph.D. and Radosław Kotkowski from the Polish Bank Association for their support in carrying out this research project. 
ket institutions. The paper presents the scope of the implementation of payment innovations and five-year plans outlined by the banks. It proved that commercial banks, including both the largest ones and those with a smaller market share, are extremely interested in payment innovations and are ready to implement many solutions at the same time. This new phenomenon can be described as the "universal innovativeness" of banks. Most of these innovations are intended to improve customer convenience, which helps banks to achieve an important strategic objective. Poland had recent changes in legal regulations which considerably reduced the interchange fee in card schemes. Our results indicated that, in spite of the decrease of the banks' revenue, the innovation process did not slow down. A new situation is coopetition between banks in Poland, used as a successful model to implement the domestic mobile payment system BLIK. The Polish market of payment services has recently become one of the most innovative in the world. The diversification of innovations implemented by the banks may be read as a strategic response of those institutions to the dynamic technological advancements of FinTech and the related uncertainty of future trends in the payment market. The results have allowed us to formulate a hypothesis that is a new paradigm of a portfolio approach to introducing payment innovations that have appeared in banking.

Keywords: payment innovation; bank strategy; payment services; FinTech; banking coopetition; interchange fee

JEL Classification: E42; G11; G21; O33

\section{INTRODUCTION}

One of the fundamental paradigms of the modern economy is the dominant role of economies of scale which, if applied, reduce unit costs of providing services and lead to a competitive advantage ${ }^{1}$. At the same time, the payment system has been strongly impacted by network externalities (also called network effects) $)^{2}$. These consist of the increase in the utility value of a given system along with the number of its participants ${ }^{3}$. In the case of set-

${ }^{1}$ J. Liebena, T. Khiaonarong, Banking on Innovation. Modernisation of Payment Systems, Physica-Verlag, Heidelberg 2009, p. 60.

2 M.L. Katz, C. Shapiro, Network externalities, competition, and compatibility, "American Economic Review”, Vol. 75, No. 3/1985, pp. 424-440; A. Iwańczuk-Kaliska, Wybrane teoretyczne i praktyczne aspekty funkcjonowania systemów ptatności detalicznych, [in:] H. Żukowska, M. Żukowski (eds.), Obrót bezgotówkowy w Polsce, Wydawnictwo KUL, Lublin 2013, pp. 103-120; R.J. Kauffman, Y.M. Wang, The network externalities hypothesis and competitive network growth, "Journal of Organizational Computing and Electronic Commerce", Vol. 12, No. 1/2002, pp. 59-83.

${ }^{3}$ L. Van Hove, Electronic money and the network externalities theory: lessons for real life, "Netnomics", Vol. 1, No. 2/1999, pp. 137-171. 
tlement systems, there are direct network effects, which are exemplified by the increased utility of bank transfers within a given funds transfer system (e.g. instant payments) along with the rise in the number of bank accounts to which payments may be made ${ }^{4}$. It is also possible to observe indirect network effects ${ }^{5}$ of payment services in the situation where the payer and recipient of the payment, use different products which, however, are complementary to each other and operate within a common standard ${ }^{6}$. For example, a holder of a payment card may use it more often when the number of payment terminals in shops rises. The merchant also experiences increased benefits from equipping the POS (Point-Of-Sale) with a EFT-POS terminal when there is a larger number of cardholders who can use cards for shopping ${ }^{7}$. The payment system is an example of a two-sided market, operating for two different groups of users which interact with each other. Pursuant to this theory, the more market users who appear on one side, the greater the benefits enjoyed by the other side of the market ${ }^{8}$.

The existence of these effects was a significant entry barrier because the implementation of a new solution or system required the development of a wide-range user network to accommodate it. The impact of network externalities is considered as one of the main reasons for the slow development of innovations in the payment services in the $20^{\text {th }}$ century ${ }^{9}$. That problem was

${ }^{4}$ D.A. Ackerberg, G. Gowrisankaran, Quantifying equilibrium network externalities in the ACH banking industry, "RAND Journal of Economics", Vol. 37, No. 3/2006, pp. 738761.

${ }^{5}$ J. Church, N. Gandal, D. Krause, Indirect network effects and adoption externalities, "Review of Network Economics", Vol. 7, No. 3/2008, pp. 337-358; S. Chakravorti, Externalities in payment card networks: Theory and evidence, "Review of Network Economics", Vol. 9, No. 2/2010; D.A. Ackerberg, G. Gowrisankaran, op. cit., pp. 738-761.

${ }^{6} \mathrm{~V}$. Stango, The economics of standards wars, "Review of Network Economics", Vol. 3, No. 1/2004, pp. 1-19.

${ }^{7} \mathrm{~J}$. Wright, Why do merchants accept payment cards?, "Review of Network Economics", Vol. 9, No. 3/2010.

${ }^{8}$ J.C. Rochet, J. Tirole, Platform competition in two-sided markets, "Journal of the European Economic Association", Vol. 1, No. 4/2003, pp. 990-1029; W. Bolt, A.F. Tieman, Heavily skewed pricing in two-sided markets, "International Journal of Industrial Organization", Vol. 26, No. 5/2008, pp. 1250-1255.

${ }_{9}$ G. Gowrisankaran, J. Stavins, Network externalities and technology adoption: Lessons from electronic payments, "RAND Journal of Economics", Vol. 35, No. 2/2004, pp. 260-276; A. Milne, What is in it for us? Network effects and bank payment innovation, "Journal of Banking and Finance”, Vol. 30, No. 6/2006, pp. 1613-1630; J. Marzec, M. Polasik, P. Fiszeder, Wykorzystanie gotówki i karty ptatniczej w punktach handlowo-ustugowych w Polsce: zastosowanie dwuwymiarowego modelu Poissona, "Bank i Kredyt", Vol. 44, No. 4/2013, pp. 375-402; M. Polasik, J. Kunkowski, K. Maciejewski, Efekt siecowy na rynku ustug ptatniczych stosowanych w handlu in- 
also presented in the first article in the series ${ }^{10}$. However, in recent years there has been observed a very dynamic development of technological innovations for the financial sector which is defined as the FinTech revolution ${ }^{11}$. Payment innovations, characterised by diversity and involvement of both banks and non-bank entities, are a major component of these new solutions ${ }^{12}$. The development of FinTech and the fact that payment innovations are often dedicated to market niches and introduce their own technical standards, raises the issue of whether the paradigms of the dominating role of economies of scale and network externalities are still in power. The answer to that question is a very interesting topic for scientific studies.

In the first article in the series, we pointed to the significant role of payment innovations in the strategies of commercial banks in Poland ${ }^{13}$. The aim of this work is to determine the involvement and plans of banks concerning the implementation of payment innovations in the Polish market. The specific objectives of the paper include: (1) examining the relationship between the scope of the payment innovations and the size of the bank; (2) determining the impact of legal regulations, including the reduction of the interchange fee, on the innovativeness of the Polish banking sector and (3) identifying the technical and market conditions which influence the policies of banks regarding the implementation of payment innovations. Taking into account the above-mentioned strong impact of the economies of scale and network externalities on the payment services market, we reach a hypothesis

ternetowym, "Zeszyty Naukowe Uniwersytetu Szczecińskiego. Ekonomiczne Problemy Usług”, No. 87/2012, pp. 546-553.

${ }^{10}$ M. Polasik, D. Piotrowski, Payment innovations in Poland: the role of payment services in the strategies of commercial banks, "Ekonomia i Prawo. Economics and Law", Vol. 15, No. $1 / 2016$.

${ }_{11}$ T. Dapp, Fintech - The digital (r)evolution in the financial sector, "Deutsche Bank Research", Frankfurt am Main 2014; T. Dapp, Fintech reloaded - Traditional banks as digital ecosystems, "Deutsche Bank Research", Frankfurt am Main 2015.

12 Deloitte, Payments disrupted. The emerging challenge for European retail banks, https://www2. deloitte.com/content/dam/Deloitte/uk/Documents/financial-services/deloitte-uk-payments-disrupted-2015.pdf (17.04.2016); S. Chakravorti, E. Kobor, Why invest in payment innovations?, "Federal Reserve Bank of Chicago Emerging Payments Occasional Paper", No. 2003-1B/2003; M. Polasik, K. Maciejewski, Innowacyjne ustugi ptatnicze w Polsce i na świecie, "Materiały i Studia NBP”, No. 241/2009; M. Polasik, K. Przenajkowska, Procesy integracyjne na europejskim rynku ustug ptatniczych w świetle badań epirycznych, "Zeszyty Naukowe Uniwersytetu Szczecińskiego. Ekonomiczne Problemy Usług”, No. 105/2013, pp. 417-425; J. Harasim, M. Klimontowicz, Payment habits as a determinant of retail payment innovations diffusion: the case of Poland, "Journal of Innovation Management", Vol. 1, No. 2/2013, pp. 86-102.

${ }^{13}$ M. Polasik, D. Piotrowski, op. cit. 
that: Commercial banks are interested in introducing only those payment innovations which have the potential to quickly gain a large market share.

\section{METHODS OF EMPIRICAL STUDIES}

Empirical studies applied in the paper were conducted as part of a research project of the Warsaw Institute of Banking Rozwój przez innowacje czy efekt skali? Badanie uczestników polskiego systemu ptatniczego [Development through innovations or economies of scale? Study of the participants of the Polish payment system] (No. WIB/2014/01). The project was implemented in the years 2014-2015 by a team under the direction of Michat Polasik, Ph.D., within ALTERUM Centre for Research and Analysis of Financial System ${ }^{14}$. The project included two surveys which were addressed to: the executives (CEOs) of banks and other institutions involved in the functioning of the payment services market (survey No. 1 - responses were the official positions of the institutions), and experts - 70 high-level managers employed in banks, banking institutions (the National Bank of Poland, the Polish Bank Association), with acquirers and in card associations and IT companies operating in the field of payment services (survey No. 2). Detailed information regarding the methodology of survey No. 1 was presented in the first article in the series ${ }^{15}$. The sample (No. 1) of 24 commercial banks is representative with respect to retail payment instruments in Poland.

\section{INVOLVEMENT OF THE BANKING SECTOR IN THE IMPLEMENTATION OF INNOVATIVE PAYMENT SERVICES}

Commercial banks were asked to declare the current status of implementations and their plans regarding individual types of payment innovations. During the study, three payment innovations were widely offered by commercial banks in Poland (figure 1). Contactless cards were the first among them: they had been implemented by all larger commercial banks and almost

${ }^{14}$ The summary of remaining results of survey No. 1 and the results of survey No. 2 is available on the website of the Warsaw Institute of Banking: M. Polasik, A. Piotrowska, N. Kumkowska, Rozwój przez innowacje czy efekt sali? Badanie uczestników polskiego systemu ptatniczego. Streszczenie kierownicze, http://alterum.pl/uploaded/Raport_Rozwoj_przez_innowacje_czy_efekt_skali_-_polski_s.pdf (17.04.2016).

${ }^{15}$ M. Polasik, D. Piotrowski, op. cit. 
$3 / 4$ of smaller commercial banks (figure 2). This great success of the contactless technology in Poland since 2007 was studied in the series of articles by M. Polasik ${ }^{16}$. It resulted both from the involvement of the banking sector and the unique technical features which make contactless cards a very fast and convenient payment method ${ }^{17}$. The second widely spread innovation were PayBy-Link ${ }^{18}$ payments dedicated to e-commerce ${ }^{19}$, offered by almost all larger commercial banks and almost $2 / 3$ of smaller commercial banks. The widespread availability and convenience of this solution were the drivers of its great success in the Polish electronic commerce market ${ }^{20}$. The third popular solution included bank transfers based on the SORBNET system, which is a large-value RTGS (Real-Time Gross Settlement) payment system run by the National Bank of Poland. However, banks may also use it to realize retail transaction, although at high fees for the customers. Within this application they perform the function of instant bank transfers, although generally the central bank is trying to limit such transactions. Actual instant payments via bank transfers, dedicated to the retail market, were offered (or were in the last stage of implementation) by $50 \%$ of commercial banks, in partic-

${ }^{16}$ M. Polasik, T.P. Wisniewski, G. Lightfoot, Modelling customers' intentions to use contactless cards, "International Journal of Banking, Accounting and Finance", Vol. 4, No. 3/2012, pp. 203231; M. Polasik, Rynek zblizeniowych kart ptatniczych w Polsce, "Zeszyty Naukowe Uniwersytetu Szczecińskiego. Ekonomiczne Problemy Usług”, No. 58/2010, pp. 241-248; M. Polasik, Rozwój rynku ptatności zbliżeniowych w Polsce, "Zeszyty Naukowe Wydziałowe Uniwersytetu Ekonomicznego w Katowicach. Studia Ekonomiczne”, No. 105/2012, pp. 399-408; M. Polasik, Perspektywy rozwoju mobilnych ptatności NFC na rynku polskim, "Annales UMCS - Sectio H Oeconomia”, Vol. XLVIII, No. 4/2014, pp. 197-207; M. Polasik, Innowacje ptatnicze stosowane w fizycznych punktach sprzedaży — szansa dla obrotu bezgotówkowego w Polsce, [in:] H. Żukowska, M. Żukowski (eds.), Obrót bezgotówkowy w Polsce, Wydawnictwo KUL, Lublin 2013, pp. 79-102.

${ }_{17}$ M. Polasik et al., Time efficiency of Point-of-Sale payment methods: Empirical results for cash, cards and mobile payments, "Lecture Notes in Business Information Processing", Springer, Heidelberg, Vol. 141/2013, pp. 306-320.

18 Pay-By-Link is a solution based on online banking service and regular bank transfers that allows the rapid execution of transactions. It informs the seller immediately without waiting for the confirmation of fund transfer through the interbank payment system. The applied online interface guarantees customer convenience and automatically fills in the transfer form. Pay-By-Link is similar to the German Sofort Banking system, but it functions in cooperation with banks (M. Polasik et al., Price fluctuations and the use of Bitcoin: An empirical inquiry, "International Journal of Electronic Commerce", Vol. 20, No. 1/2015, pp. 9-49).

${ }_{19}$ G. Szymański, Innowacje marketingowe w sektorze e-commerce, Wydawnictwo Politechniki Łódzkiej, Łódź 2013.

${ }^{20}$ J. Kunkowski, M. Polasik, Polski rynek ptatności internetowych: stan i uwarunkowania rozwoju, [in:] A. Stabryła, K. Woźniak (eds.), Determinanty potencjatu rozwoju organizacji, Mfiles. pl, Kraków 2012, pp. 71-85. 
ular larger banks (63\%). In Poland, instant payments are offered within two competing systems: the Express Elixir system maintained by the Automated Clearing House KIR (Krajowa Izba Rozliczeniowa), and the BlueCash system maintained by the company Blue Media. It should be added that Poland was the second country in Europe to implement instant payments after the United Kingdom with its pioneer Faster Payments system ${ }^{21}$.

Particular attention should be paid to the service of mobile payments in applications connected with the customer's current account. During the study, customers were able to use them in the case of two banks, i.e.: PKO BP via the IKO solution, and Bank Pekao via the PeoPay solution ${ }^{22}$. However, further six banks were at an advanced stage of implementation of the BLIK system which is a development of the IKO system ${ }^{23}$. It was established on the basis of an agreement signed by six commercial banks in 2013 regarding cooperation aimed to create a common local mobile payments standard under the BLIK brand. Within that solution, each bank is responsible for preparing its own application for mobile payments, typically integrated into mobile banking, while the BLIK system is managed by Polski Standard Płatności, a company whose shareholders are the six founding banks. Operational services for the BLIK system are provided by KIR. The BLIK system officially started in February $2015^{24}$, i.e. after the study had finished; however, due to the advanced stage of implementations in banks this solution was classified as "offered to customers or implemented". It is worth noting that the cooperation between competing banks regarding a common standard for mobile payments is a classic example of the so-called coopetition (see more in chapter 7), which helped this standard to very quickly achieve a positive network externalities and critical mass of users ${ }^{25}$. As a result, the imple-

${ }^{21}$ N. Kumkowska, Wykorzystanie systemów ptatności natychmiastowych w Unii Europejskiej, [in:] A. Krzysztofek (ed.), Finansowanie dziatalności przedsiębiorstw a spoteczna odpowiedzialnośc biznesu, AT Wydawnictwo, Kraków 2014, pp. 129-138.

${ }_{22}$ Moreover, as part of the iKasa solution customers of Getin Bank and Alior Bank could make payments in the Biedronka commercial network. However, due to the limited acceptance range this solution is not classified as mobile payments for general purposes.

${ }^{23}$ M. Kisiel, Modele systemów ptatności mobilnych a źródta pieniq̨dza oraz mechanizmy rozracbunku transakcji, "Copernican Journal of Finance \& Accounting”, Vol. 2, No. 2/2013, pp. 6173; M. Polasik, N. Kumkowska, Determinanty zainteresowania ptatnościami mobilnymi ze strony polskich konsumentów, "Problemy Zarządzania", Vol. 13, No. 3/2015, pp. 102-117.

${ }^{24}$ The following commercial banks are the current participants of BLIK: Alior Bank, BZ WBK, ING, mBank, Millennium, PKO BP, Getin Bank and Neo Bank (a cooperative bank) (Polski Standard Płatności, http://www.polskistandardplatnosci.pl (17.04.2016)).

25 J. Górka, Efektywność instrumentów ptatniczych w Polsce, Wydawnictwo Naukowe Wydziału Zarządzania Uniwersytetu Warszawskiego, Warszawa 2013, pp. 45-46. 
mentation range of bank mobile payments based on applications (figure 1) reached 35\% among all banks and as much as 59\% for larger commercial banks (figure 2), and most Polish current account holders were able to use this service in their bank. Moreover, an additional 35\% of commercial banks, primarily smaller banks, are planning to introduce this solution by joining the BLIK standard.

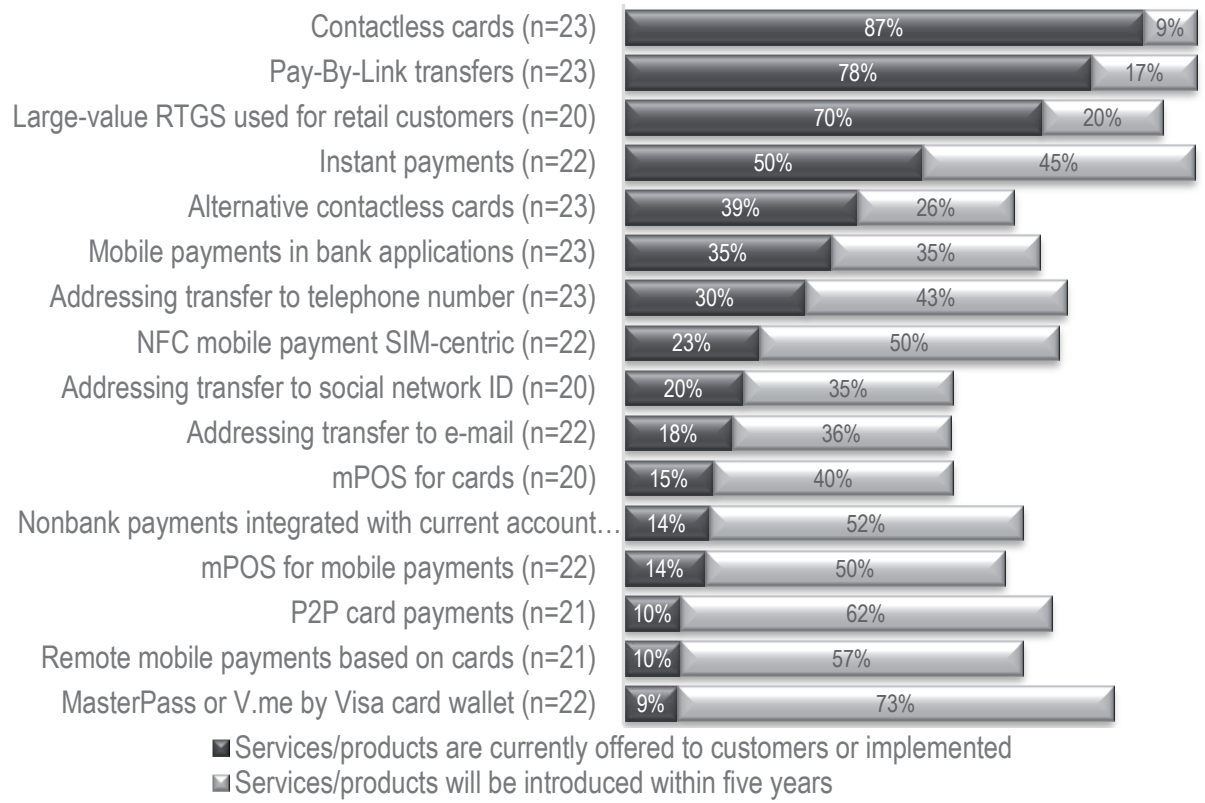

Figure 1. Status of implementations of payment innovations by commercial banks

Source: Survey among commercial banks; Q24. What is the status of implementations of payment innovations in your Bank?

Several of the innovative services were widely widespread, yet not exceeding half of the surveyed commercial banks (figure 1). These include: alternative contactless cards (different physical form, e.g.: watches, key fobs, contactless stickers), bank transfers addressed to a telephone number, a social network ID or email address. These solutions were generally far more popular among larger banks (figure 2) [e.g. alternative contactless cards - 66\%, addressing transfers to a telephone number - 42\%]. In general, the advancement of these services was significantly lower in smaller banks, with an exception for addressing transfers to social network IDs. Other payment innovations were characterised by a meagre implementation range, although each of them was offered or implemented by at least two banks. 
The plans for the following five years declared by banks suggest a radical change in attitude to payment innovations. This new approach should be defined as "mass innovation" because it may be assumed that in the 2020 perspective there is a chance that all of the 16 examined innovations will be offered by at least half of commercial banks (figure 1). The service which was intended for implementation by the largest number of banks was the MasterPass or V.me by Visa card wallet. The fact that almost 3/4 of the banks are planning to implement virtual card wallets for these solutions is indicative of their enormous perceived potential in e-commerce. Moreover, it is also probable that MasterCard and Visa card associations have provided attractive conditions for banks to implement them.

Special importance should be attributed to plans regarding widespread introduction of instant payments for bank transfers which will be offered by almost all banks and will in fact become a standard service in the Polish retail banking sector. There is also a clearly visible trend related to the future introduction of different solutions facilitating the customer in addressing bank transfers (to a telephone number, social network ID, email address), what is undoubtedly in compliance with the general drive to guarantee convenient use of services to the customer, and what may make this traditional payment instrument more attractive. This trend to improve customer convenience is also exemplified by the solution of non-bank payments integrated with the current account ${ }^{26}$ which are applied in e-commerce (a model tested within the PayU Express service and mTransfer Mobile). It is also worth noting that the vast majority of larger banks plans to implement P2P (Person-to-Person) card payments which are beginning to be promoted by card associations (figure 2). P2P card payments enable convenient remittance, private settlements or money transfers between cards registered in the platform. However, it may prove to be a difficult task to popularise these services because in Poland payments between individuals are currently strongly dominated by the use of the bank transfer. The convenient method of addressing them may additionally strengthen the position of bank transfers in that market segment.

${ }_{26}$ The term non-bank payments integrated with current account refers to the solution in which an external payment service provider, e.g. a payment processor, integrates that service into the interface of its platform supporting sales for e-commerce or m-commerce. After the customer selects this payment method during shopping their bank account is automatically debited without additional authorisation (up to a certain cap amount) on the basis of their previous consent granted to the bank and the agreement between the bank and the non-bank provider. 


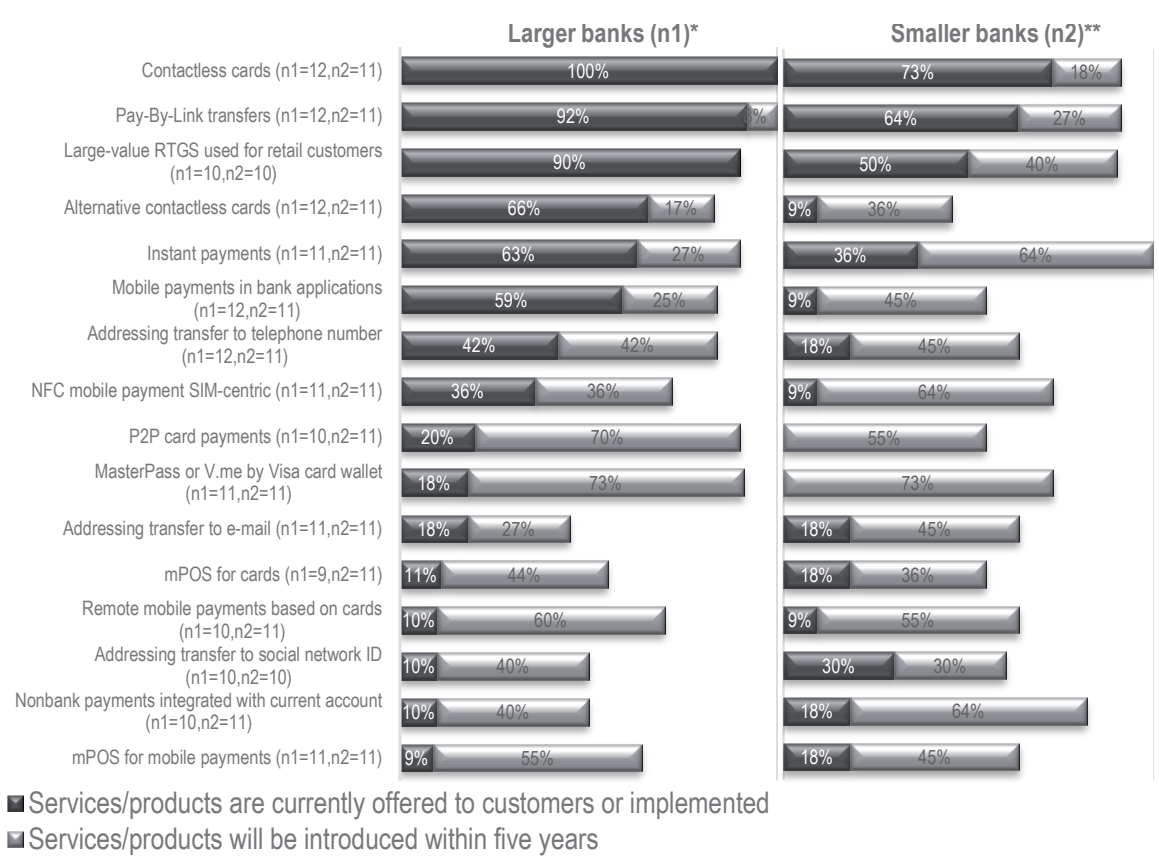

Figure 2. Status of implementations of payment innovations (by size of bank)

* "Larger banks" - means the 12 commercial banks with the largest number of current accounts maintained; ** "Smaller banks" - means the group of the remaining 12 commercial banks with a smaller number of current accounts maintained Source: Survey among commercial banks.

Source: Survey among commercial banks; Q24. What is the status of implementations of payment innovations in your Bank?

In the field of mobile payments, the banks' plans suggest the competition between three important solutions. The abovementioned mobile payments in bank applications, implemented by most large banks, are the first of them. However, they may face competition in the segment of electronic commerce payments and in the bill payments from remote mobile payments based on cards, as $67 \%$ of the banks are planning to introduce the latter. In turn, in the segment of transactions in physical POS, large interest was shown in NFC mobile payments which have been implemented by more than $1 / 3$ of the banks and half of the banks declared that they were planning to introduce them (figure 1). If we consider the fact that the question referred to NFC payments in the technology based on the SIM card (the socalled SIM-Centric model ${ }^{27}$ ) and that currently we observe the dynamic development of a newer and more effective technology based on HCE (Host

${ }^{27}$ M. Polasik, Perspektywy rozwoju..., op. cit. 
Card Emulation) ${ }^{28}$, it can turn out that the attractiveness of NFC mobile payments will increase significantly. The segment of mobile payments is an example of how banks implement or plan to implement several solutions, competitive to one another, at the same time.

On the other hand, solutions like $\mathrm{mPOS}^{29}$ are an example of services not planned to be introduced in the coming years by a large group of banks (figure 1$)^{30}$. We have a similar situation with regard to addressing payments to e-mail or social network ID. Individual types of mobile payments also have their own groups of sceptics. It is an important clue that as many as half of larger commercial banks (figure 2) reject the possibility to make non-bank payments integrated with current account (e.g. PayU Express) available to their customers, while smaller commercial banks are rather interested in that solution (figure 2). This is related to the fact that in this solution control over the relation with the customer is taken over to a large extent by an external provider. Large institutions do not accept such situation and they prefer to promote their own solutions.

It should be underlined that the banks, in particular larger commercial banks, declared the providing of convenience of service use by customers is a priority in competing in the field of payment services (see figure 2 in the first article in the series ${ }^{31}-83 \%$ of indications for convenience feature among larger banks). It is clearly confirmed by the analysis of the list of the abovementioned 16 innovations. In case of as many as 9 of them it was the improvement of customer convenience the main feature of a given solution and not the development of functionalities or effectiveness. Innovations aimed at customer convenience include: contactless cards, Pay-By-Link payments, alternative contactless cards, NFC payments, addressing transfers to a telephone number, social network ID or e-mail, payments integrated with current account and MasterPass or V.me by Visa payments.

28 NFC Forum, NFC Forum Statement Regarding Host Card Emulation (HCE), http://nfc-forum.org/newsroom/nfc-forum-statement-regarding-host-card-emulation-hce (17.04.2016).

${ }^{29} \mathrm{mPOS}$ is a technical solution which makes it possible to accept cashless payments, including payments using traditional payment cards, with the use of a mobile device (in particular a smartphone or a tablet) without the need to use a traditional EFT-POS terminal (M. Polasik, Potencjat rozwoju ptatności mobilnych $i$ zastosowania mPOS na rynku polskim: Wyniki badań empirycznych, "Problemy Zarządzania", Vol. 13, No. 3/2015, pp. 65-84).

${ }^{30}$ This may be related to the fact that in the period of the study most banks in Poland did not operate as acquirers and did not offer entrepreneurs the option to accept card payments. Therefore, they cannot have been interested in the mPOS solution which would require becoming involved in this field of operations.

${ }^{31}$ M. Polasik, D. Piotrowski, op. cit. 


\section{UNIVERSAL INNOVATIVENESS IN THE RETAIL PAYMENT MARKET}

In order to determine the general level of involvement of individual banks in the introduction of payment innovations, we calculated two aggregates referring to the abovementioned list of services which was subject to the study (figure 1). These aggregates are: (a) the sum of payment services which were offered to customers or implemented during the study and (b) the sum of services which banks plan to introduce within five years (figure 3).

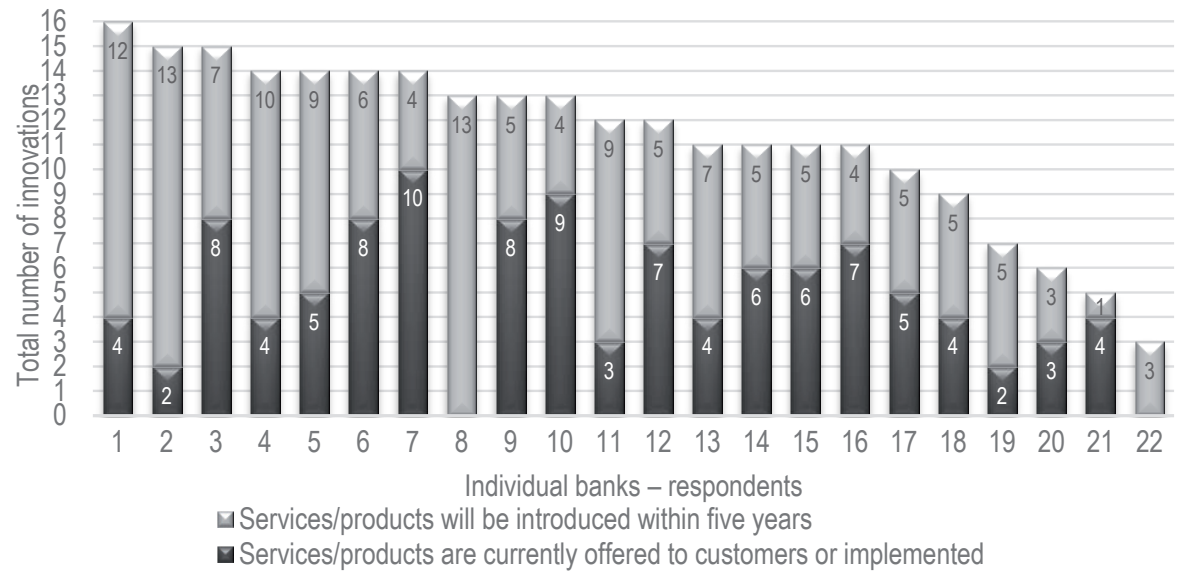

Figure 3. Number of payment innovations offered or planned for implementation by individual banks

Source: Survey among commercial banks; Q24. What is the status of implementations of payment innovations in your Bank?

Taking into consideration that the total number of analysed innovations was 16, the results achieved indicate highly ambitious plans related to the implementation of the services by most of banks (figure 3). From among the 22 banks under consideration (in two cases answers were lacking), as many as five institutions already offered half or more of the studied services, while a vast majority of banks are planning to have most of these services on offer within the next five years (only four of them did not declare that). As many as seven banks declared the implementation of practically every available payment innovation (at least 14 services). Therefore, the results obtained allow us to conclude that the Polish banking sector is experiencing a phenomenon which may be defined as a "universal innovativeness". Considering that many of the analysed solutions are competitive to one another and the five-year perspective is relatively long, it should be assumed that not all of these plans will be fulfilled. However, the Polish banking sec- 
tor is currently exhibiting a very clear trend to introduce diverse payment innovations on a far larger scale than before.

The Table 1 allows us to compare the involvement in innovation within the groups of larger and smaller commercial banks. Without doubt, during the study larger commercial banks offered a broader range of innovative payment services because their average number was 6.18, as compared to 3.73 for smaller banks. However, smaller commercial banks declared the willingness to take up the challenge of innovativeness of payment services and the average number of such services which are planned for implementation within the next five years is much higher as far as they are concerned (7.27, as compared to 5.45 for larger banks).

Table 1. Average involvement of banks in the implementation of payment innovations

\begin{tabular}{|c|c|c|c|c|c|c|} 
& \multicolumn{2}{|c|}{$\begin{array}{l}\text { AVERAGE NUMBER AND } \\
\text { PERCENTAGE* OF SERVI- } \\
\text { CES CURRENTLY OFFERED } \\
\text { TO CUS-TOMERS OR IMPLE- } \\
\text { MENTED }\end{array}$} & $\begin{array}{c}\text { AVERAGE NUMBER AND } \\
\text { PERCENTAGE* OF SERVICES } \\
\text { WHICH WILL BE INTRODU- } \\
\text { CED WITHIN FIVE YEARS }\end{array}$ & $\begin{array}{c}\text { AVERAGE NUMBER AND } \\
\text { PERCENTAGE* OF SERVICES } \\
\text { FORECAST TO BE OFFERED } \\
\text { IN 2020** }\end{array}$ \\
\cline { 2 - 7 } & NUMBER & PERCENTAGE & NUMBER & PERCENTAGE & NUMBER & PERCENTAGE \\
\hline Banks in total $(n=22)$ & 4.95 & $31 \%$ & 6.36 & $40 \%$ & 11.32 & $71 \%$ \\
\hline Larger banks $(n=11)$ & 6.18 & $39 \%$ & 5.45 & $34 \%$ & 11.64 & $73 \%$ \\
\hline Smaller banks $(n=11)$ & 3.73 & $23 \%$ & 7.27 & $45 \%$ & 11.00 & $69 \%$ \\
\hline
\end{tabular}

* The percentage of introduced services was calculated in relation to all 16 surveyed services (figure 1); ** The forecast number of services to be offered in 2020 was calculated on the assumption that implemented services will not be withdrawn from the market by the banks, which is unlikely due to the substitutability between individual services. Source: Survey among commercial banks.

As a result, in 2020 the differences between larger and smaller commercial banks with respect to the forecast offer of innovative payment services may be relatively small. Although we can wonder whether smaller banks will be able to allocate sufficient investment outlays in order to actually implement those ambitious plans, these results confirm that the conviction of the necessity of universal and multidirectional involvement in the development of payment services regards practically the entire commercial banking sector in Poland. 


\section{REGULATION OF FOUR-PARTY CARD SCHEMES AND DEVELOPMENT OF INNOVATIONS}

The interchange fee is an important element of the business model of four-party payment card schemes, used e.g. by Visa and MasterCard ${ }^{32}$. It is charged by acquirers from merchants accepting cards as an amount calculated on the value of payment and constitutes revenue for issuers of payment cards, i.e. banks ${ }^{33}$. Since the 1990s, the payment card market in Poland was characterised by a high level of interchange fee which was among the highest in the European Union ${ }^{34}$. This situation resulted in very good profitability of card issuance business for banks but it was met by objections of the merchant community which was bearing this fee ${ }^{35}$. As a result of consultations carried out by the National Bank of Poland and subsequent works in the Parliament, on 30 August 2013 an amendment of the Act on Payment Services $^{36}$ was adopted ${ }^{37}$. With effect from 1 July 2014, it introduced a limit of the interchange fee amounting to a maximum of around $0.5 \%$ of the value of transactions carried out using payment cards, while in 2013 the fee was around $1.3 \%$. It meant a drastic reduction of banks' revenue from that fee by a staggering $62 \%$. It was followed by another amendment of the abovementioned Act of 28 November $2014^{38}$, under which the interchange fee was reduced to a level of $0.2 \%$ of the value of transactions for debit cards and $0.3 \%$ for credit cards, effective from 29 January 2015, which deepened the decrease of IF in relation to the initial level by about $85 \%$. The scale of those radical changes disturbed the foundations of the four-party card scheme business

${ }^{32}$ J. Rochet, J. Tirole, Must-take cards: Merchant discounts and avoided costs, "Journal of the European Economic Association", Vol. 9, No. 3/2011, pp. 462-495.

33 A. Börestam, H. Schmiedel, Interchange fees in card payments, "ECB Occasional Paper Series”, No. 131/2011; M. Polasik, Analiza potencjalnych skutków stosowania surchargingu dla rynku kart ptatniczych, "Prace Naukowe Uniwersytetu Ekonomicznego we Wrocławiu", No. 124/2010, pp. 148-168.

${ }^{34}$ K. Maciejewski, Znaczenie optaty interchange dla rozwoju rynku kart ptatniczych w Polsce, “Copernican Journal of Finance \& Accounting”, Vol. 2, No. 2/2013, pp. 111-124.

${ }^{35} \mathrm{~J}$. Górka, Merchant indifference test application - A case for revising interchange fee level in Poland, "The usage, costs and benefits of cash - revisited. Proceedings of the 2014 International Cash Conference”, Deutsche Bundesbank, Frankfurt am Main 2014, pp. 75-151.

${ }^{36}$ Ustawa z dnia 30 sierpnia 2013 r. o zmianie ustawy o ustugach ptatniczych, (Act of 30 August 2013 amending Act on Payment Services), Dz.U. 2013, item 1271.

37 J. Byrski, Nowelizacja ustawy o ustugach ptatniczych dotyczqca optaty interchange - komentarz praktyczny, Warszawa 2014.

38 Ustawa z dnia 28 listopada 2014 r. o zmianie ustawy o ustugach ptatniczych (Act of 28 November 2014 amending Act on Payment Services), Dz.U. 2014, item 1916. 
model which was successfully implemented by banks in Poland for almost two decades. Naturally, it gave rise to a question regarding the impact of the legal regulations on the development of the payment services market in Poland ${ }^{39}$, and in particular on the innovativeness of the Polish banking sector which used to invest a part of the income from the interchange fee in new payment solutions, e.g. contactless cards ${ }^{40}$.

We performed a general assessment of the significance of the abovementioned regulatory changes on the basis of the expert part of the survey (Survey No. 2 - see chapter 1 ). It turned out that according to $3 / 4$ of Polish experts, the reduction of the interchange fee was by far the biggest challenge in the Polish payment market for the year 2015 ${ }^{41}$. It confirms the fact that in the years 2014-2015 we were dealing with a regulatory shock in the payment cards market in Poland. The reduction of the interchange fee pushed other challenges for the payment services market, related to technological advances or price competition, into the background. On the other hand, in the long-term perspective individual challenges faced by the participants of the Polish payment market will change. In general, experts believe that by 2020 the problem regarding the adjustment of the business model for payment cards will be successfully solved and will no longer be a significant issue. In turn, the role of the biggest challenge for the banking sector, both in Poland and in whole Europe, will be taken by non-bank competitors gaining a share in the market. Competition from entities which are just entering the market apparently generates high risk for its current participants. Therefore, the next most important challenges for the banking sector will be the ability to introduce innovations into the market and the implementation of new technologies, including mobile technologies.

When considering the direct effects of the reduction of the interchange fee in Poland, the experts had their say with regard to the possibility of fulfilment of a number of potential scenarios (figure 4). The first establishment of a maximum rate of the interchange fee was in force from 1 July 2014 and this regulation meant a reduction of this fee from around $1.3 \%$ to a maximum of $0.5 \%$ of the value of card payments. The respondents referred to that first change, and assessed the projected effects of the regulation (the second reduction of the interchange fee was carried out after the survey had ended). Most experts forecast that the reduction of the interchange fee will re-

${ }^{39} \mathrm{~J}$. Harasim, Regulacje jako determinanta rozwoju innowacji na rynku ptatności de-talicznych, "Annales UMCS - Sectio H Oeconomia", Vol. XLVII, No. 3/2013, pp. 219-228.

${ }^{40}$ M. Polasik, Rozwój rynku ptatności..., op. cit., pp. 399-408.

${ }^{41}$ M. Polasik, A. Piotrowska, N. Kumkowska, op. cit. 
sult in a significant development of the EFT-POS terminals network (figure 4). Moreover, the study revealed that there is a consensus of almost all experts regarding the expected increase in fees for bank customers related to the servicing and issuance of payment cards, and regarding the fact that competition in the banking market will be rather unable to stop this process.

Reduction of consumer activation programmes $(n=66)$

Increase in fees for bank customers $(\mathrm{n}=67)$

Banks search for other solutions reducing costs of servicing cards* $(n=66)$

Banks issue alternative payment instruments, e.g. mobile payments $(n=66)$

Significant expansion of the EFT-POS terminals network $(n=67)$

Strong competition will prevent banks from raising fees ${ }^{* *}(n=66)$

Suppression of the introduction of payment innovations $(n=66)$

- Strongly agree

$\square$ Agree

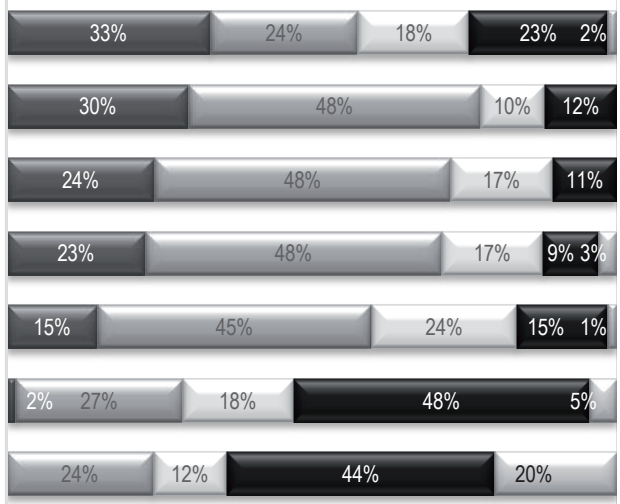

Disagree $\square$ Strongly disagree

Figure 4. Effects of the reduction of the interchange fee in the short-term perspective

* Banks will search for other solutions reducing the costs of servicing cards, e.g. cooperation with another entity assessing transactions of Visa/MasterCard; ** Fees related to the servicing and issuance of payment cards.

Source: Survey among experts; Q43. Do you agree with the statements regarding the forecast effects of the reduction of the interchange fee in Poland to the level of around $0.5 \%$ from July 2014 ?

On the other hand, it is a very favourable forecast for the Polish market that a majority of experts do not fear that regulatory changes will suppress the introduction of payment innovations in the Polish market (figure 4). Quite the contrary, the prevailing view is that they will contribute to the issuance of new payment instruments alternative to cards, e.g. in the field of mobile payments. This phenomenon is also confirmed by the abovementioned plans of the banks regarding the introduction of innovations (figures 1 and 3 ). The regulatory factor is surely only one of many stimuli for the development of new services. Nevertheless, the results of the survey suggest that the reduction of the interchange fee may actually contribute to the acceleration of the process of implementation of payment innovations which may potentially become a new revenue area for banks, also through eliminating cash transaction ${ }^{42}$. Therefore, the process of implementation of payment innovations contributes to the achievements of objectives of the Polish Programme

42 Ibidem. 
for the Development of Cashless Transactions implemented by the Coalition for Cashless Transactions and Micropayments, including the National Bank of Poland ${ }^{43}$.

\section{PORTFOLIO APPROACH TO INTRODUCING PAYMENT INNOVATIONS}

From the viewpoint of banks' allocation of resources, it appears that the introduction of innovative payment services within strategies of commercial banks is currently a very big challenge connected with an uncertainty factor. New product development has always been a high-risk venture for banks ${ }^{44}$. The first paper in the series ${ }^{45}$ discusses the fact that less than $1 / 4$ of the newly-introduced banking products achieve the assumed profitability level ${ }^{46}$. Currently, the FinTech revolution is constantly increasing the scale of uncertainty. It should be noted that in the case of many highly-innovative payment services, like bitcoin ${ }^{47}$, only several years earlier we were not able to envisage the scale of their popularity and scope of use. Contactless cards are another good example - their first tests in the Polish market began in 2007 and already in 2010 we had mass migration to that standard covering millions of cards and tens of thousands of payment terminals ${ }^{48}$. Few market analysts also managed to foresee the dynamic development of mobile banking because the market of smartphones with touchscreens, connected to an application platform and mobile Internet grew at such a pace that it was a surprise. Thus, earlier considerations acknowledging the limitations of cellphones' functionalities with comparison to the Internet channel as a permanent barrier to the development of mobile banking, unexpectedly became obsolete ${ }^{49}$. Interesting observations regarding the lack of predictabili-

${ }^{43}$ Koalicja na Rzecz Obrotu Bezgotówkowego i Mikropłatności, Program Rozwoju Obrotu Bezgotórwkowego w Polsce na lata 2014-2020, Warszawa 2013, http://zbp.pl/dla-bankow/zespoly-rady-i-komitety/podaj-nazwe/obrot-bezgotowkowy/koalicja (17.04.2016).

${ }^{44}$ I. Alam, Innovation Strategy, Process and Performance in the Commercial Banking Industry, "Journal of Marketing Management", Vol. 19, No. 9/2003, pp. 973-999.

${ }^{45}$ M. Polasik, D. Piotrowski, op. cit.

46 Simon-Kucher \& Partners, Global Pricing Study 2014. Kryzys w innowacyjności? 72\% nowych produktów wprowadzanych na rynek to porażki, http://www.simon-kucher.com/sites/default/files/global_pricing_study_2014_podsumowanie.pdf (17.04.2016).

${ }^{47}$ M. Polasik et al., Price fuctuations..., op. cit., pp. 9-49.

${ }^{48}$ M. Polasik, T.P. Wisniewski, G. Lightfoot, op. cit., pp. 203-231.

${ }^{49}$ A. Górna, Innowacje w operacjach bankowych dla klientów indywidualnych, [in:] A. Gospodarowicz (ed.), Innowacje w operacjach bankowych, Wydawnictwo Akademii Ekonomicznej we Wrocławiu, Wrocław 2003, pp. 168-181. 
ty of the directions and dynamics of changes in the scope of the use of new technologies in banking were formulated by the author of mBank's success, president Sławomir Lachowski. In his opinion, in the early stages "banks introduced Internet banking out of obligation in order to avoid being accused of omission and to keep up with the competition, and not in order to work out a strategic competitive advantage". However, on the other hand "leaders of the New Economy have built their position almost entirely thanks to product innovations and novel business concepts"50.

The abovementioned examples point to the existence of very high uncertainty regarding forecasting the directions of development of the payment services market. Rapid technological advancements and highly intense competition in that market segment, also from non-banking entities, cause the banks to implement a new strategy of introducing payment innovations into the market, which is unusual for these financial institutions. Banks no longer limit themselves to the involvement only in proven solutions with high probability of achieving economies of scale and positive network externalities. Quite the contrary, commercial banks carry out a policy of implementing a very large number of payment innovations (figure 3), often with competitive features. This is in contrast to the fact that relatively few banks indicated pursuing competition through offering a wide range of payment services (see the first article in the series ${ }^{51}$ ). These results suggest that the banks not so much strive to offer as many payment services to the customers as possible, but rather carry out many implementations of payment innovations in order to increase the chance that one of them will become successful and will help achieve other important elements of the strategy, i.e. customer convenience of using services and multichannelling ${ }^{52}$. Such rational actions aim to diversify risk related to investing in payment innovations through simultaneous involvement in many solutions. It can therefore be argued that the strategies of commercial banks in the scope of the development of payment services in the Polish market indicate vast similarities to the model of functioning of venture capital funds ${ }^{53}$.

50 S. Lachowski, Droga innowacji, Studio EMKA, Warszawa 2010, p. 130.

${ }^{51}$ M. Polasik, D. Piotrowski, op. cit.

${ }^{52}$ W. Piotrowicz, R. Cuthbertson, Introduction to the Special Issue: Information Technology in Retail: Toward Omnichannel Retailing, "International Journal of Electronic Commerce", Vol. 18, No. 4/2014, pp. 5-16.

${ }^{53}$ W. Przybylska-Kapuścińska, M. Eukowski, Fundusze private equity $i$ venture capital $i$ ich znaczenie dla gospodarki, "Studia Ekonomiczne. Zeszyty Naukowe Uniwersytetu Ekonomicznego w Katowicach”, No. 186/2014, pp. 287-300. 
Thus, there is strong evidence, both empirical and theoretical, to reject hypothesis, pursuant to which: Commercial banks are interested in introducing only those payment innovations which disclose the potential to quickly gain a large market share. The abovementioned approach of banks to innovations, backed by empirical results, allows us to formulate a hypothesis that a new paradigm has appeared in banking, and it consists in a portfolio approach of introducing payment innovations. The term "portfolio approach" was introduced for the purposes of this paper due to the similarity of innovative activities of the banks to investment strategies based on portfolio analysis and the concept of risk diversification. However, the portfolio approach to introducing payment innovations takes rather the form of portfolio methods applied in strategic analysis, such as the Ansoff matrix and their derivatives ${ }^{54}$.

\section{SIGNIFICANCE OF TECHNOLOGICAL ADVANCEMENTS IN THE FINTECH INDUSTRY}

It should be noted that the possibility to apply a portfolio approach to introducing payment innovations has appeared thanks to technological advancements and the development of FinTech enterprises, because there was a very significant reduction of the costs of creating and implementing new IT systems, also in the field of payment solutions. As a result, at relatively low outlays even small banks are able to purchase solutions adjusted to their needs from external suppliers ${ }^{55}$. Due to strong competition in the FinTech sector $^{56}$, these solutions are not only cost effective but can also be quickly implemented. It is due to such initially small investment outlays and the availability of outsourcing that the banks may afford to introduce a large number of innovations, taking into account the fact that some of them will not be successful. On the other hand, significant outlays related to promotional activities and activating consumers are allocated only to those solutions which some time after implementation prove to be prospective. This suggests that the risk related to implementing new payment services is seen by most banks as lower than the risk of lagging behind the competition.

${ }^{54}$ S. Kasiewicz, L. Kukliński, M. Marcinkowska, Sektor bankowy - motor czy bamulec wzrostu gospodarczego, ALTERUM Ośrodek Badań i Analiz Systemu Finansowego, Zakład Warszawskiego Instytutu Bankowości, Warszawa 2013, p. 55; M. Romanowska, G. Gierszewska, Analiza strategiczna przedsiębiorstwa, PWE, Warszawa 2009.

${ }_{55}$ T. Dapp, Fintech reloaded..., op. cit.

${ }^{56}$ T. Dapp, Fintech - The digital..., op. cit.; Deloitte, op. cit. 
The possibility to use the differentiation strategy at a very large scale is an additional consequence of low implementation costs. This regards in particular electronic commerce which has experienced strong segmentation of payment services. Thanks to using outsourcing, some of the banks introduce products dedicated to individual market niches which satisfy specific needs and ensure maximum customer convenience ${ }^{57}$, e.g. in $\mathrm{m}$-commerce transactions. This happens at the cost of economies of scale and therefore low initial investment outlays are an important stimulus for these innovations. Studies conducted in the United States have shown that it is precisely the innovations dedicated to market niches that are most successful, as opposed to many solutions dedicated to the mass-market. Although the latter achieve a large scale of operations, they undergo the process of commoditisation and provide a very low profit margin $^{58}$.

\section{COOPETITION AND UNIVERSAL INNOVATIVENESS IN THE POLISH MARKET}

It should be underlined that the extremely high willingness of banks to introduce innovations significantly distinguishes the Polish market from most countries of the world. According to the studies of The Forrester Research, innovative electronic banking is an area in which the Polish market is a European leader ${ }^{59}$. Even banks in the United States take inspiration from Polish solutions ${ }^{60}$. According to G. Hansen, one of the important results of such high innovativeness is that banks have obtained the so-called domestic competitive advantage which is a significant barrier to entry to the market for foreign competitors ${ }^{61}$. This regards both credit institutions operating under the single European passport and non-bank entities. If such entity started offering payment services in Poland, it would have to face the need to introduce cutting-edge solutions which are already expected by the customers. The advantage of domestic banks is strengthened by the popularity of specific

57 Ibidem; M. Polasik, K. Maciejewski, op. cit.

58 S. Chakravorti, E. Kobor, op. cit.

59 P. Wannemacher, A. L'Hostis, 2015 Global Mobile Banking Functionality Benchmark, Cambridge 2015.

${ }^{60}$ Forbes, Najciekawsze innowacje w polskiej bankowości, http://www.forbes.pl/najciekawsze-innowacje-w-polskiej-bankowosci,artykuly,192012,1,1.html (17.04.2016).

${ }^{61} \mathrm{G}$. Hansen, Innowacje w bankach sq mato zyskowne, ale dajq inny efekt, http://www.obserwatorfinansowy.pl/tematyka/bankowosc/innowacje-w-bankach-sa-malo-zyskowne-ale-daja-inny-efekt (17.04.2016). 
local standards for payment innovations, such as Pay-By-Link or instant payments, and the BLIK mobile payment system.

That last solution requires particular attention due to the fact that it is an example of cooperation between competing banks - the so-called coopetition $^{62}$. It is a fairly new phenomenon in the Polish banking services market. Coopetition provides potentially large benefits to its participants, in particular in a payment system were network externalities and economies of scale play a key part. The fact that the domestic mobile payment standard, offered within the BLIK system, was introduced within a coopetition model allowed it to become available to as many as $60 \%$ of bank customers in Poland right from the $\operatorname{start}^{63}$. The banks also managed to quickly provide users with access to a large network of ATMs and payment terminals servicing the BLIK standard. It allowed them to achieve positive network externalities extremely quickly. However, success in the market will depend on the effectiveness of individual banks in the scope of promoting the active use of these mobile payments and the ability to provide customers with added value.

\section{BANKS AS INNOVATORS — VISION AND LIMITATIONS}

The abovementioned considerations referring to the strategic approach of banks to introducing payment innovations allow us to formulate a certain long-term vision regarding the future role of banks in the Polish economy. M. Marcinkowska situates banks in the role of "initiators of the development of technology", and she does not use this term narrowly to refer only to the world of finance ${ }^{64}$. Moreover, D. Korenik formulates a view that "the bank of the future is destined to continuously create innovative services" 65 . Therefore, making the introduction of innovations the basis for a bank's strategy allows it not only to adjust to reality but also to reach out further, answer the challenges of the future or even to form the future. The future role

${ }^{62}$ D.S. Evans, R. Schmalensee, Paying with Plastic. The Digital Revolution in Buying and Borrowing, MIT Press, Cambridge, MA 2004, p. 61.

${ }^{63}$ Z. Jagiełło (ed.), Wyzwania bankowości detalicznej, Instytut Badań nad Gospodarką Rynkową, Gdańsk 2015, http:/www.efcongress.com/sites/default/files/wyzwania_bankowosci_ detalicznej_2015.pdf (14.04.2016).

${ }^{64}$ M. Marcinkowska, Bank jutra..., czyli rozważania o przysztości sektora bankowego, [in:] J. Nowakowski (ed.), W kierunku nowego tadu świata finansów, Oficyna Wydawnicza SGH, Warszawa 2015, pp. 23-47.

${ }^{65}$ D. Korenik, Bank i jego ustugi w dobie „rewolucji finansowej”, [in:] D. Korenik (ed.), Innowacyjne ustugi banku, PWN, Warszawa 2006, p. 37. 
of banks is seen even wider by J.K. Solarz. In his opinion, apart from managing different risks and capital, banks will initiate and carry out social processes, implement innovations in this area ${ }^{66}$. According to that vision, banks would become providers of knowledge and innovative technological solutions using the concept of open architecture for financial platforms to that aim ${ }^{67}$.

However, it seems that there are certain conditions which may potentially impede the banks' fulfilment of that vision. One of them is the issue of whether banks can obtain sufficient IT competencies which would allow them to perform a complex transformation of their manner of functioning. We must take into account that the nature of banking services requires concentration on that activity and that the past development of payment innovations was achieved to a large extent thanks to the cooperation and outsourcing of technological companies. Therefore, we may doubt whether it is possible for banks to achieve a leading role in the FinTech area on their own, especially when we consider that some of banking innovations may be copied by imitators with relative ease ${ }^{68}$. Thus, we are faced with the question regarding the durability of the strategy of portfolio approach to payment innovations, currently implemented by banks in Poland.

The dynamic development of non-bank competitors that introduce their payment solutions on an increasingly large scale may be another potential threat to the innovativeness of banks. This may be exemplified by payment products offered by global technological corporations, such as Apple Pay, Samsung Pay or Google Wallet ${ }^{69}$. Market strength of these companies will surely support attracting customers to their solutions.

At the same time, we can expect significant changes in the regulatory environment of the payment services market in the European Union, in particular in the scope of introducing access to the bank account for Third-Party Payment Providers (TPP) within the prepared amendment of the Payment Services Directive $(\mathrm{PSD} 2)^{70}$. This gives rise to concerns

${ }^{66}$ J.K. Solarz, Metodologiczne aspekty projekcji rozwoju sektora bankowego w Polsce do roku 2030, [in:] J. Szambelańczyk (ed.), Polski sektor bankowy w perspektywie roku 2030, Oficyna Wydawnicza SGH, Warszawa 2010, pp. 13-26.

${ }^{67}$ M. Marcinkowska, Innowacje finansowe w bankach, "Acta Universitatis Lodziensis. Folia Oeconomica”, No. 266/2012, pp. 71-96; L. Dziawgo, Open-product architecture. Inspirujaca koncepcja oferowania produktów i ustug finansowych, "eFinanse", Vol. 1, No. 1/2005.

${ }_{68}$ M. Marcinkowska, op. cit., pp. 71-96.

${ }^{69}$ Deloitte, op. cit.

${ }^{70}$ W. Szpringer, M. Szpringer, Innowacje w ptatnościach elektronicznych - tendencje rozwojowe, "Problemy Zarządzania", Vol. 13, No. 54/2015, pp. 11-28; T. Dapp, Fintech reloaded..., op. cit.; M. Polasik, A. Piotrowska, N. Kumkowska, op. cit. 
whether the role of banks will not be brought down to providing a source of money and information for third parties which will implement their own payment innovations. Therefore, it is possible that banks of the future will return to a more conservative policy in the scope of innovation, and specialised entities operating as TPP will deal in creating and testing new solutions. According to this unfavourable vision, banks would function simply as public utility companies, and banking payment services would undergo permanent commoditisation and would provide only a small margin. However, we can hope that banks will be able to benefit from their current potential and build a lasting competitive advantage. In such situation, technological companies challenging banks and new regulations may have a positive effect in the form of further increase of innovativeness of the banking sector.

\section{CONCLUSIONS}

In this work, we presented the results of empirical studies on the actual scope of the implementation of particular payment solutions and fiveyear plans declared by the banks. The analysis we conducted indicates that the Polish payment services market experiences the phenomenon of "universal innovativeness". It found that commercial banks display an extremely high interest in payment innovations and a readiness to implement many solutions that are competitive with each other, at the same time. Interestingly, this applied to not only the largest banks but also those with a smaller market share. Most of the implemented payment innovations are intended to increase customer convenience. They are not focused on developing functionalities or the effectiveness of services, which is confirmed by the fact that convenience is the strategic priority.

The conviction of the necessity of universal and multidirectional involvement in the development of payment services is shared by almost the entire commercial banking sector in Poland. Empirical results suggest that we need to modify the existing paradigm that the dominant role in banking and payment systems is dependent on economies of scale and network externalities. The dynamic progress of FinTech and the related uncertainty have caused financial institutions to implement elements of strategies previously used by venture capital funds. They have decided to apply the portfolio approach, which we identified, that consists in investing in many payment innovations in the early stages of their development. Therefore, we should reject the second research hypothesis that commercial banks are interested in intro- 
ducing only those payment innovations which have the potential to quickly gain a large market share.

These processes have established the Polish banking sector as one of the European leaders in terms of payment innovations. One of the most promising phenomena is the introduction of the domestic mobile payment system offered under the BLIK brand within a model of coopetition between banks. It allowed them to quickly create a large user network and infrastructure for accepting this standard among merchants. The first effects of the regulatory reduction of the interchange fee in Poland is an important guideline for other member states and the European Commission. The results of the survey among banks, as well as the results obtained during the supplementary survey among experts have shown that the negative forecasts did not materialise. The change did not hinder the introduction of payment innovations in the Polish market. Quite the contrary, it led to the development of payment instruments that were alternatives to cards, including mobile payments.

The dynamic development of non-bank competitors that have introduced their payment solutions on an increasingly large scale, based on unique technological advantages, may be a potential long-term threat to the innovativeness of banks. At the same time, revolutionary changes of the regulatory environment projected in the payment services market in the European Union are being prepared under the amendment of the Payment Services Directive (PSD2). In particular, introducing access to bank accounts for Third-Party Payment Providers may have a significant impact on the competitive landscape in the payment innovations. However, on the basis of the results presented in this paper, it is possible to conclude that the Polish banking system is now far better equipped to face future challenges than several years ago. It seems justified that banks in other European countries should benefit from the Polish experiences.

\section{FUTURE STUDIES}

The studies conducted in the paper led to the formulation of a new hypothesis, where banks apply the portfolio approach in order to market numerous payment innovations. If this hypothesis were to be confirmed, it would provide support for creating a new paradigm in the scope of the functioning of the banking sector. However, verification of this hypothesis requires further in-depth scientific studies which would enable researchers to understand the decision-making processes in banks that are responsible for the phenomenon of "universal innovativeness" observed in Poland. It will also be neces- 
sary to determine whether the portfolio approach to payment innovations is of a permanent nature.

Another promising line of research is an attempt to quantify the level of innovativeness of individual payment services markets in Europe in order to establish whether the high level of innovativeness observed in Poland may be treated as a domestic competitive advantage representing a significant barrier to entry.

The third very interesting area for future studies is the assessment of the long-term impact of the reduction of the interchange fee in payment card schemes on the innovativeness of the banking sector. These studies could preferably include a comparative analysis with the situation in other countries which have observed changes in the business model regarding the functioning of payment cards.

\section{BIBLIOGRAPHY}

Ackerberg D.A., Gowrisankaran G., Quantifying equilibrium network externalities in the ACH banking industry, "RAND Journal of Economics", Vol. 37, No. 3/2006, http://doi.org/10.1111/j.1756-2171.2006.tb00040.x.

Alam I., Innovation Strategy, Process and Performance in the Commercial Banking Industry, "Journal of Marketing Management", Vol. 19, No. 9/2003, http://doi.org/1 0.1080/0267257X.2003.9728247.

Bolt W., Tieman A.F., Heavily skewed pricing in two-sided markets, "International Journal of Industrial Organization", Vol. 26, No. 5/2008, http://doi.org/10.1016/j. ijindorg.2007.11.003.

Börestam A., Schmiedel H., Interchange fees in card payments, "ECB Occasional Paper Series", No. 131/2011.

Byrski J., Nowelizacja ustawy o ustugach ptatniczych dotyczaca optaty interchange - komentarz praktyczny, Warszawa 2014.

Chakravorti S., Externalities in payment card networks: Theory and evidence, "Review of Network Economics", Vol. 9, No. 2/2010, http://doi.org/10.2202/14469022.1199.

Chakravorti S., Kobor E., Why invest in payment innovations?, "Federal Reserve Bank of Chicago Emerging Payments Occasional Paper”, No. 2003-1B/2003.

Church J., Gandal N., Krause D., Indirect network effects and adoption externalities, "Review of Network Economics", Vol. 7, No. 3/2008, http://doi.org/10.2202/14469022.1153.

Dapp T., Fintech - The digital (r)evolution in the financial sector, "Deutsche Bank Research", Frankfurt am Main 2014.

Dapp T., Fintech reloaded - Traditional banks as digital ecosystems, "Deutsche Bank Research”, Frankfurt am Main 2015. 
Deloitte, Payments disrupted. The emerging challenge for European retail banks, https:// www2.deloitte.com/content/dam/Deloitte/uk/Documents/financial-services/deloitte-uk-payments-disrupted-2015.pdf (17.04.2016).

Dziawgo L., Open-product architecture. Inspirujaca koncepcja oferowania produktów $i$ ustug finansowych, "eFinanse", Vol. 1, No. 1/2005.

Evans D.S., Schmalensee R., Paying with Plastic. The Digital Revolution in Buying and Borrowing, MIT Press, Cambridge, MA 2004.

Forbes, Najciekawsze innowacje w polskiej bankowości, http://www.forbes.pl/najciekawsze-innowacje-w-polskiej-bankowosci,artykuly,192012,1,1.html (17.04.2016).

Górka J., Efektywnośc instrumentów ptatniczych w Polsce, Wydawnictwo Naukowe Wydziału Zarządzania Uniwersytetu Warszawskiego, Warszawa 2013.

Górka J., Merchant indifference test application - A case for revising interchange fee level in Poland, "The usage, costs and benefits of cash - revisited. Proceedings of the 2014 International Cash Conference", Deutsche Bundesbank, Frankfurt am Main 2014.

Górna A., Innowacje w operacjach bankowych dla klientów indywidualnych, [in:] A. Gospodarowicz (ed.), Innowacje w operacjach bankowych, Wydawnictwo Akademii Ekonomicznej we Wrocławiu, Wrocław 2003.

Gowrisankaran G., Stavins J., Network externalities and technology adoption: Lessons from electronic payments, "RAND Journal of Economics", Vol. 35, No. 2/2004, http://doi.org/10.2307/1593691.

Hansen G., Innowacje w bankach sq mato zyskowne, ale daja inny efekt, http://www. obserwatorfinansowy.p1/tematyka/bankowosc/innowacje-w-bankach-sa-malo-zyskowne-ale-daja-inny-efekt (17.04.2016).

Harasim J., Klimontowicz M., Payment habits as a determinant of retail payment innovations diffusion: the case of Poland, "Journal of Innovation Management", Vol. 1, No. 2/2013.

Harasim J., Regulacje jako determinanta rozwoju innowacji na rynku ptatności detalicznych, "Annales UMCS - Sectio H Oeconomia", Vol. XLVII, No. 3/2013.

Iwańczuk-Kaliska A., Wybrane teoretyczne i praktyczne aspekty funkcjonowania systemórw ptatności detalicznych, [in:] H. Żukowska, M. Żukowski (eds.), Obrót bezgotórwkowy w Polsce, Wydawnictwo KUL, Lublin 2013.

Jagiełło Z. (ed.), Wyzwania bankowości detalicznej, Instytut Badań nad Gospodarką Rynkową, Gdańsk 2015, http://www.efcongress.com/sites/default/files/wyzwania_ bankowosci_detalicznej_2015.pdf (14.04.2016).

Kasiewicz S., Kukliński L., Marcinkowska M., Sektor bankowy - motor czy bamulec wzrostu gospodarczego, ALTERUM Ośrodek Badań i Analiz Systemu Finansowego, Zakład Warszawskiego Instytutu Bankowości, Warszawa 2013.

Katz M.L., Shapiro C., Network externalities, competition, and compatibility, "American Economic Review", Vol. 75, No. 3/1985.

Kauffman R.J., Wang Y.M., The network externalities hypothesis and competitive network growth, "Journal of Organizational Computing and Electronic Commerce", Vol. 12, No. 1/2002, http://doi.org/10.1207/S15327744JOCE1201_05. 
Kisiel M., Modele systemórw ptatności mobilnych a žródta pieniądza oraz mechanizmy rozrachunku transakcji, "Copernican Journal of Finance \& Accounting", Vol. 2, No. 2/2013, http://doi.org/10.12775/CJFA.2013.016.

Koalicja na Rzecz Obrotu Bezgotówkowego i Mikropłatności, Program Rozwoju Obrotu Bezgotórwkowego w Polsce na lata 2014-2020, Warszawa 2013, http://zbp.pl/ dla-bankow/zespoly-rady-i-komitety/podaj-nazwe/obrot-bezgotowkowy/koalicja (17.04.2016).

Korenik D., Bank i jego ustugi w dobie „rewolucji finansowej”, [in:] D. Korenik (ed.), Innowacyjne ustugi banku, PWN, Warszawa 2006.

Kumkowska N., Wykorzystanie systemów ptatności natychmiastowych w Unii Europejskiej, [in:] A. Krzysztofek (ed.), Finansowanie dziatalności przedsiębiorstw a spoteczna odpowiedzialność biznesu, AT Wydawnictwo, Kraków 2014.

Kunkowski J., Polasik M., Polski rynek ptatności internetowych: stan i uwarunkowania rozwoju, [in:] A. Stabryła, K. Woźniak (eds.), Determinanty potencjatu rozwoju organizacji, Mfiles.pl, Kraków 2012.

Lachowski S., Droga innowacji, Studio EMKA, Warszawa 2010.

Liebena J., Khiaonarong T., Banking on Innovation. Modernisation of Payment Systems, Physica-Verlag, Heidelberg 2009, http://doi.org/10.1007/978-3-7908-2333-2.

Maciejewski K., Znaczenie optaty interchange dla rozwoju rynku kart ptatniczych w Polsce, "Copernican Journal of Finance \& Accounting", Vol. 2, No. 2/2013, http:// doi.org/10.12775/CJFA.2013.019.

Marcinkowska M., Bank jutra..., czyli rozważania o przysztości sektora bankowego, [in:] J. Nowakowski (ed.), $W$ kierunku nowego tadu świata finansów, Oficyna Wydawnicza SGH, Warszawa 2015.

Marcinkowska M., Innowacje finansowe w bankach, "Acta Universitatis Lodziensis. Folia Oeconomica", No. 266/2012.

Marzec J., Polasik M., Fiszeder P., Wykorzystanie gotówki i karty ptatniczej w punktach handlowo-ustugowych w Polsce: zastosowanie dwuwymiarowego modelu Poissona, "Bank i Kredyt", Vol. 44, No. 4/2013.

Milne A., What is in it for us? Network effects and bank payment innovation, "Journal of Banking and Finance", Vol. 30, No. 6/2006, http://doi.org/10.1016/j. jbankfin.2005.09.006.

NFC Forum, NFC Forum Statement Regarding Host Card Emulation (HCE), http:// $\mathrm{nfc}$-forum.org/newsroom/nfc-forum-statement-regarding-host-card-emulation-hce (17.04.2016).

Piotrowicz W., Cuthbertson R., Introduction to the Special Issue: Information Technology in Retail: Toward Omnichannel Retailing, "International Journal of Electronic Commerce", Vol. 18, No. 4/2014, http://doi.org/10.2753/JEC1086-4415180400. Polasik M., Analiza potencjalnych skutków stosowania surchargingu dla rynku kart ptatniczych, "Prace Naukowe Uniwersytetu Ekonomicznego we Wrocławiu", No. $124 / 2010$.

Polasik M., Górka J., Wilczewski G., Kunkowski J., Przenajkowska K., Tetkowska N., Time efficiency of Point-of-Sale payment methods: Empirical results for cash, cards 
and mobile payments, "Lecture Notes in Business Information Processing", Springer, Heidelberg, Vol. 141/2013, http://doi.org/10.1007/978-3-642-40654-6_19.

Polasik M., Innowacje ptatnicze stosowane w fizycznych punktach sprzedaży — szansa dla obrotu bezgotówkowego w Polsce, [in:] H. Żukowska, M. Żukowski (eds.), Obrót bezgotórwkowy w Polsce, Wydawnictwo KUL, Lublin 2013.

Polasik M., Kumkowska N., Determinanty zainteresowania platnościami mobilnymi ze strony polskich konsumentów, "Problemy Zarządzania", Vol. 13, No. 3/2015, http:// doi.org/10.7172/1644-9584.54.7.

Polasik M., Kunkowski J., Maciejewski K., Efekt siecowy na rynku ustug ptatniczych stosowanych w handlu internetowym, "Zeszyty Naukowe Uniwersytetu Szczecińskiego. Ekonomiczne Problemy Usług”, No. 87/2012.

Polasik M., Maciejewski K., Innowacyjne ustugi ptatnicze w Polsce i na świecie, "Materiały i Studia NBP”, No. 241/2009.

Polasik M., Perspektywy rozwoju mobilnych ptatności NFC na rynku polskim, "Annales UMCS — Sectio H Oeconomia", Vol. XLVIII, No. 4/2014.

Polasik M., Piotrowska A., Kumkowska N., Rozwój przez innowacje czy efekt sali? Badanie uczestników polskiego systemu ptatniczego. Streszczenie kierownicze, http://alterum.pl/uploaded/Raport_Rozwoj_przez_innowacje_czy_efekt_skali_-_polski_s. pdf (17.04.2016).

Polasik M., Piotrowska A., Wisniewski T.P., Kotkowski R., Lightfoot G., Price fuctuations and the use of Bitcoin: An empirical inquiry, "International Journal of Electronic Commerce”, Vol. 20, No. 1/2015, http://doi.org/10.1080/10864415.2016 .1061413 .

Polasik M., Piotrowski D., Payment innovations in Poland: the role of payment services in the strategies of commercial banks, "Ekonomia i Prawo. Economics and Law", Vol. 15, No. 1/2016, http://dx.doi.org/10.12775/EiP.2016.006.

Polasik M., Potencjat rozwoju ptatności mobilnych i zastosowania mPOS na rynku polskim: Wyniki badań empirycznych, "Problemy Zarządzania", Vol. 13, No. 3/2015, http://doi.org/10.7172/1644-9584.54.5.

Polasik M., Przenajkowska K., Procesy integracyjne na europejskim rynku ustug ptatniczych w świetle badań epirycznych, "Zeszyty Naukowe Uniwersytetu Szczecińskiego. Ekonomiczne Problemy Usług", No. 105/2013.

Polasik M., Rozwój rynku ptatności zbliżeniowych w Polsce, "Zeszyty Naukowe Wydziałowe Uniwersytetu Ekonomicznego w Katowicach. Studia Ekonomiczne”, No. $105 / 2012$.

Polasik M., Rynek zbliżeniowych kart ptatniczych w Polsce, "Zeszyty Naukowe Uniwersytetu Szczecińskiego. Ekonomiczne Problemy Usług”, No. 58/2010.

Polasik M., Wisniewski T.P., Lightfoot G., Modelling customers' intentions to use contactless cards, "International Journal of Banking, Accounting and Finance", Vol. 4, No. 3/2012, http://doi.org/10.1504/IJBAAF.2012.051590.

Polski Standard Płatności, http://www.polskistandardplatnosci.pl (17.04.2016). 
Przybylska-Kapuścińska W., Łukowski M., Fundusze private equity $i$ venture capital $i$ ich znaczenie dla gospodarki, "Studia Ekonomiczne. Zeszyty Naukowe Uniwersytetu Ekonomicznego w Katowicach", No. 186/2014.

Rochet J., Tirole J., Must-take cards: Merchant discounts and avoided costs, "Journal of the European Economic Association", Vol. 9, No. 3/2011, http://doi. org/10.1111/j.1542-4774.2011.01020.x.

Rochet J.C., Tirole J., Platform competition in two-sided markets, "Journal of the European Economic Association", Vol. 1, No. 4/2003.

Romanowska M., Gierszewska G., Analiza strategiczna przedsiębiorstwa, PWE, Warszawa 2009.

Simon-Kucher \& Partners, Global Pricing Study 2014. Kryzys w innowacyjności? 72\% nowych produktów wprowadzanych na rynek to porażki, http://www.simon-kucher.com/sites/default/files/global_pricing_study_2014_podsumowanie.pdf (17.04.2016).

Solarz J.K., Metodologiczne aspekty projekcji rozwoju sektora bankowego w Polsce do roku 2030, [in:] J. Szambelańczyk (ed.), Polski sektor bankowy w perspektywie roku 2030, Oficyna Wydawnicza SGH, Warszawa 2010.

Stango V., The economics of standards wars, "Review of Network Economics", Vol. 3, No. 1/2004, http://doi.org/10.2202/1446-9022.1040.

Szpringer W., Szpringer M., Innowacje w ptatnościach elektronicznych - tendencje rozwojowe, "Problemy Zarządzania", Vol. 13, No. 54/2015, http://dx.doi. org/10.7172/1644-9584.54.1.

Szymański G., Innowacje marketingowe w sektorze e-commerce, Wydawnictwo Politechniki Łódzkiej, Łódź 2013.

Ustawa z dnia 28 listopada 2014 r. o zmianie ustawy o ustugach ptatniczych (Act of 28 November 2014 amending Act on Payment Services), Dz.U. 2014, item 1916.

Ustawa z dnia 30 sierpnia 2013 r. o zmianie ustawy o ustugach ptatniczych, (Act of 30 August 2013 amending Act on Payment Services), Dz.U. 2013, item 1271.

Van Hove L., Electronic money and the network externalities theory: lessons for real life, "Netnomics", Vol. 1, No. 2/1999.

Wannemacher P., L'Hostis A., 2015 Global Mobile Banking Functionality Benchmark, Cambridge 2015.

Wright J., Why do merchants accept payment cards?, "Review of Network Economics", Vol. 9, No. 3/2010. http://doi.org/10.2202/1446-9022.1221. 